\title{
Surveilans Newcastle Disease (ND) pada Unggas di Papua Barat
}

\author{
Sulaxono Hadi ${ }^{1 *}$, Ratna Loventa Sulaxono ${ }^{1}$ \\ ${ }^{1}$ Balai Besar Veteriner Maros \\ *Corresponding author: idahonoxalus@gmail.com
}

\begin{abstract}
Abstrak
Newcastle Disease merupakan penyakit viral menular pada unggas yang disebabkan oleh strain virulen Avian Paramyxovirus-1 (vAPMV-1), bisa menyebab kematian yang besar pada unggas tertular. Kegiatan surveilans telah dilakukan oleh Balai Besar Veteriner Maros di provinsi Papua Barat dalam rangka deteksi dini serta mengetahui sirkulasi virus ND pada beberapa jenis unggas di beberapa kabupaten pada ternak unggas. Sebanyak 215 pool swab orofaring unggas dari ayam buras, ayam broiler, ayam layer, itik, entog dan puyuh. Sampel diambil dari 2 kabupaten/kota, 8 kecamatan, 10 desa. Pengujian terhadap sampel swab unggas tersebut di lakukan di Laboratoium Virologi dengan metode isolasi pada telur specific pathogen free (SPF). Hasilnya menunjukkan ditemukan 5 pool swab positif terhadap ND dari 15 pool swab pada ayam broiler di Kabupaten Manokwari. Bioskuriti dan vaksinasi ND perlu dilakukan di lokasi peternakan untuk mencegah serangan ND.
\end{abstract}

Kata kunci: Isolasi, Newcastle disease, Unggas

\section{Abstract}

Newcastle Disease is a viral disease transmitted in poultry caused by virulent strain avian paramyxovirus-1 (vAPMV-1), which can cause major deaths in infected poultry. Surveillance activities have been conducted by the Maros Veterinary Center in West Papua Province in order to early detection and know the circulation of ND virus in some types of poultry in several chicken, layer chicken, duck, muscovy duck and quail. A total of 215 poultry oropharyngeal swab pools from native chickens, broilers, layer chickens, ducks, muscovy ducks and quail. Samples were taken from 2 districts/cities, 8 subdistricts, 10 villages. Testing of poultry swab samples was conducted in Laboratoium Virology with isolation methode on eggs specific pahogene free (SPF). The results showed that 5 positive from 15 swab pools were found against ND in broiler chickens Manokwari Distric. Biosecurity and ND vaccinations need to be carried out at the farm site to prevent ND attacks.

Keywords: Isolation, Newcastle disease, Poultry 
Prosiding Seminar Nasional Pembangunan dan Pendidikan Vokasi Pertanian

Politeknik Pembangunan Pertanian Manokwari, 31 Juli 2021

e ISSN : 2774-1982

DOI : https://doi.org/10.47687/snppvp.v2i1.178

\section{PENDAHULUAN}

Provinsi Papua Barat memiliki potensi untuk pengembangan ternak unggas untuk memenuhi kebutuhan protein hewani masyarakat. Populasi unggas di provinsi ini berdasarkan data yang ada tahun 2019 meliputi ayam buras sebanyak 1.435 .744 ekor, ayam broiler 721.089 ekor, ayam layer 456.706 ekor, itik 95.799 ekor, entog 5.317 ekor dan puyuh 2.300 ekor (Narullah et al., 2019).

Dalam pengembangan ternak unggas aspek manajemen memegang peran penting, mencakup tata laksana pakan, bioskuriti, pencegahan dan pengendalian penyakit. Cukup banyak penyakit pada unggas yang disebabkan oleh berbagai agen penyebab dapat berdampak pada timbulnya kerugian ekonomi, akibat pertumbuhan yang terhambat, inefisiensi penggunaan pakan, serta kematian. Salah satu penyakit penting pada ternak unggas yang disebabkan oleh virus dan mengakibatkan morbiditas serta mortalitas yang tinggi adalah Newcastle Disease (ND) atau Penyakit Tetelo.

ND disebabkan oleh virus genus Orthoavulavirus, famili Paramyxovirus (OIE, 2021). Strain virulen dari famili ini adalah Avian Paramyxovirus Tipe 1 (APMV-1). Penyakit ini tersebar di seluruh dunia, termasuk di Indonesia. Infeksi virus ND pada ayam dapat menyebabkan terjadinya anoreksia, diare, drop produksi telur, serta kematian. Morbiditas pada ayam tervaksin ND berkisar 5-10\% pada individu ayam serta 5-15\% pada flok, dengan penurunan produksi pada ayam layer berkisar 2,89-3,50\% (Balachandran et al., 2014). Morbiditas dan mortalitas bisa mencapai $100 \%$ pada ayam yang tidak tervaksinasi ND (OIE, 2021).

Virus ND dapat ditemukan bersirkulasi di lingkungan usaha peternakan dan mengancam populasi unggas yang ada. Virus bisa berasal dari kandang lain tertular, alat transportasi, pekerja kandang, peralatan kandang, rodensia atau oleh burung liar. Mohammed et al. (2020) telah menemukan dan mengisolasi virus ND dari berbagai jenis burung liar sebanyak 3,77\% dari 159 sampel burung liar. Sebagian jenis burung liar ini juga berkeliaran sekitar kandang ayam. Virus ND dapat ditemukan pada unggas yang tidak menunjukkan klinis ND. Thomazelli et al. (2012) telah mengidentikasi virus ND pada unggas yang tidak menunjukkan klinis ND, yang berpotensi pembawa virus dan menularkan ke unggas lainnya yang rentan.

Balai Besar Veteriner Maros dalam rangka berperan serta untuk pengendalian ND khususnya di Papua Barat telah melakukan surveilans pada berbagai jenis unggas dengan 
Prosiding Seminar Nasional Pembangunan dan Pendidikan Vokasi Pertanian

Politeknik Pembangunan Pertanian Manokwari, 31 Juli 2021

e ISSN : 2774-1982

DOI : https://doi.org/10.47687/snppvp.v2i1.178

melakukan pengambilan sampel swab orofaring unggas serta melakukan pengujian laboratorium untuk deteksi dini sirkulasi virus pada usaha peternakan unggas.

\section{METODE}

Sebanyak 215 pool swab orofaring unggas dengan rincian 169 pool swab ayam buras, 15 pool swab ayam broiler, 18 pool swab ayam layer, 10 pool swab itik, 3 ekor pool swab entok, 5 pool swab puyuh, yang berasal dari 2 kabupaten/kota, 8 kecamatan dan 10 desa digunakan untuk isolasi virus ND.

Metode isolasi dilakukan menggunakan telur specific pathogen free (SPF) berembrio umur 9 hari. Sampel swab dari unggas dihomogenkan dengan larutan phosphate buffer saline (PBS) 10\%, ditambahkan streptomycin $2 \mathrm{mg} / \mathrm{ml}$ dan penicilline $2.000 \mathrm{IU} / \mathrm{ml}$, disentrifuge $2.000 \mathrm{rpm}$ selama 15 menit. Supernatan $0,1 \mathrm{ml}$ diinokulasikan pada alantois telur, diinkubasi pada suhu $37^{\circ} \mathrm{C}$ selama 6 hari. Candling dilakukan tiap 2 hari. Pada telur yang embrionya mati, disimpan di refrigerator bersuhu $4{ }^{\circ} \mathrm{C}$. Cairan alantois pada embrio yang mati dideteksi dengan hemaglutinin menggunakan RBC $1 \%$ untuk melihat adanya aglutinasi yang menandakan adanya virus ND.

\section{HASIL DAN PEMBAHASAN}

Dari 220 sampel swab orofaring dari berbagai jenis unggas yang diuji melalui metode isolasi untuk virus ND (Tabel 1), isolat virus hanya ditemukan pada jenis ayam broiler. Dari sebanyak 15 swab orofaring ayam broiler yang diambil dari Manokwari, sampel positif hanya ditemukan pada peternakan broiler komersial di desa Wosi, kecamatan Manowari Barat. Sebanyak 5 sampel pool swab positif terisolasi virus ND dari 15 sampel pool swab ayam broiler. Proporsi pool swab orofaring yang positif pada ayam broiler ini sebesar 33,33\%.

Kasozi et al. (2014) menemukan 2,1\% isolat virus ND dengan cara serupa di Uganda. Hasan et al. (2010) mengisolasi virus ND sebesar 23,4\% dari broiler yang sakit serta $4,8 \%$ pada ayam layer yang sakit. Pada unggas yang tidak menunjukkan sakit, Ometto et al. (2012) menemukan 0,7\% dari 1.022 sampel yang diuji dengan metode lain RT-qPCR. 
Prosiding Seminar Nasional Pembangunan dan Pendidikan Vokasi Pertanian

Politeknik Pembangunan Pertanian Manokwari, 31 Juli 2021

e ISSN : 2774-1982

DOI : https://doi.org/10.47687/snppvp.v2i1.178

Tabel. 1. Lokasi dan jumlah pengambilan pool swab orofaring

\begin{tabular}{|c|c|c|c|c|c|c|c|c|}
\hline Kabupaten/kota & Kecamatan & $\begin{array}{l}\text { Ayam } \\
\text { buras }\end{array}$ & $\begin{array}{l}\text { Ayam } \\
\text { broiler }\end{array}$ & $\begin{array}{l}\text { Ayam } \\
\text { layer }\end{array}$ & Itik & Entog & Puyuh & $\mathrm{Jml}$ \\
\hline \multirow[t]{3}{*}{ Kota Sorong } & Sorong Timur & 10 & 0 & 0 & 0 & 0 & 0 & 10 \\
\hline & Sorong Manoi & 19 & 0 & 0 & 0 & 0 & 0 & 19 \\
\hline & $\begin{array}{l}\text { Klaurung } \\
\text { Manokwari }\end{array}$ & 40 & 0 & 0 & 0 & 0 & 0 & 40 \\
\hline \multirow[t]{6}{*}{ Manokwari } & Barat & 85 & 10 & 0 & 10 & 3 & 5 & 113 \\
\hline & $\begin{array}{l}\text { Sowi } \\
\text { Manokwari }\end{array}$ & 10 & 5 & 0 & 0 & 0 & 0 & 15 \\
\hline & Timur & 5 & 0 & 0 & 0 & 0 & 0 & 5 \\
\hline & Mariat & 0 & 0 & 8 & 0 & 0 & 0 & 8 \\
\hline & Aimas & 0 & 0 & 5 & 0 & 0 & 0 & 5 \\
\hline & Total & 169 & 15 & 13 & 10 & 3 & 5 & 215 \\
\hline
\end{tabular}

Isolasi virus ND merupakan gold standard untuk identifikasi virus ND. Mahboob et al. (2020) telah melakukan kegiatan penelitian untuk isolasi virus ND pada unggas di Arab Saudi. Wabah yang mematikan banyak ayam terutama disebabkan oleh virus ND yang sangat virulen, vvND. Ashraf et al. (2016) telah mengidentifikasi wabah ND di Brazilia adalah karena serangan very virulent $\mathrm{ND}$ (vvND).

Surveilans dengan mengambil sampel swab orofaring atau trakhea lebih baik dibandingkan dengan swab kloka. Haque et al. (2010) menemukan virus ND pada 90\% swab trakhea, sedangkan pada swab kloaka yang hanya ditemukan $85 \%$ virus ND. Okpanachi et al. (2020) menggunakan kombinasi swab faring dan kloaka untuk isolasi virus ND.

Surveilans sebenarnya tidak hanya dilakukan di lokasi usaha peternakan tetapi juga perlu dilakukan pada pasar unggas hidup, live bird market (LBM) seperti yang dilakukan oleh Msoffe et al. (2019) yang menemukan virus ND pada 10\% dari sampel yang diambil. Surveilans pada unggas di LBM juga bisa dilakukan untuk kepentingan identifikasi strain virus yang bersirkulasi seperti yang dilakukan oleh Choi et al. (2012) yang menemukan adanya strain lentogenik pada unggas di pasar unggas hidup di Korea.

Pada saat terjadi kasus dan kematian karena ND, sampel pengujian yang diperlukan adalah organ tubuh untuk pengujian dengan metode real time PCR. Metode ini lebih sensitif dan lebih cepat dilakukan dibanding isolasi virus (Mazumder et al., 2012), dengan menggunakan primer spesifik pada target gen $\mathrm{F}$ (Shanmuganathan et al., 2017). Virus ND paling banyak ditemukan pada organ limpa dibandingkan pada paru, otak dan kolon ayam (Haque et al., 2010). Pada saat terjadi wabah ND, langkah isolasi virus, identifikasi virus, 
Prosiding Seminar Nasional Pembangunan dan Pendidikan Vokasi Pertanian

Politeknik Pembangunan Pertanian Manokwari, 31 Juli 2021

e ISSN : 2774-1982

DOI : https://doi.org/10.47687/snppvp.v2i1.178

perlu dilanjutkan juga dengan fenotiping virus untuk mengetahui kekerabatan virus yang berasal dari propinsi atau negara lain seperti yang dilakukan oleh Alsahami et al. (2018) di Oman yang mengetahui bahwa virus ND di Oman 99\% mirip dengan virus ND di Pakistan.

\section{KESIMPULAN DAN SARAN}

Dari hasil surveilans, pengujian dengan isolasi virus terhadap sampel yang diambil pada berbagai unggas di Provinsi Papua Barat, virus ND ditemukan pada ayam broiler dengan jumlah positif sebanyak 5 pool swab dari 15 sampel pool swab orofaring ayam broiler.

Disarankan agar vaksinasi ND pada peternakan ayam broiler di desa Wosi, Manowari Barat dilakukan dengan baik, menerapkan manajemen bioskuriti secara ketat agar tidak terjadi kematian akibat serangan virus ND.

\section{DAFTAR PUSTAKA}

Ashaf, A., Shah, M.S., Habib, M., Hussain, M., Mahboob, S., \& Al-Ghanim, K. (2016). Isolation, identification and molecular characterization of highly pathogenic Newcastle disease viruses from field outbreaks. Human and Anim Health Braz. Arch. Bull. Technol, 59.

Balachandran, P., Srinivasan, P., Sivaseelan, S., Balasubramaniam, G.A., \& Merthy, G.K. (2014). Isolation and characterization od Newcatle disease virus from vaccinated commercial layer chickens. Vet. Word., 7(7) : 457-462.

Choi, K.S., Lee, E.K., Jeon, W.J., Kwon, J.H., Lee, J.H., \& Sung, H.W. (2012). Molecular epidemiology investigation of lentogenic Newcastle disease virus from domestic birds at live birds at live bird market in Korea. Avian Dis., 56: 218-223.

Haque, M.H., Hossain, M.F., Islam, M.T., Zinnah, M.A., Khan, M.S.R., \& Islam, M. (2020). Isolation and detection of Newcatle disease virus from field outbreak in broiler and layer chickens by reverse trancriptation polymerase chain reaction. Bangladesh J. of Vet. Med., 8 (2): 87-92.

Hasan, A.K.M.R., Ali, M.H., Siddique, M.P., Rahman, M.M., \& Islam, M.M. (2020). Clinical and laboratory diagnosis of Newcastle disease and infection bursal disease of chickens. Bangladesh J. Vet. Med., 8(2): 131-140.

Isahami, A.A., Ideris, A., Omar, A., Ramanoon, S.Z., \& Sadiq, M.B. (2018). Isolation, isolation and molecular characterization of Newcastle disease viruses in vaccinated chickens from commercial farms in the Sultanate of Oman. Int J. of Vet Sci and Med., 6: 248-252.

Kosozi, K.I., Ssuna, P., Tayebwa, D.S., \& Alyas, M. (2014). Newcastle disease virus isolation and its prevalence in Uganda poultry farms. Open J. of Vet. Med., 4(1): $1-5$.

Mahboob, S., Qadeer, M., Al-Ghanim, K.A., Al-Misned, F., \& Al-Mulhim, N. (2020). Isolation identification and molecular characterization of Newcastle disease virus using SDS-PAG. J. of King Saud Univ. Sci., 32: 1000-1003. 
Prosiding Seminar Nasional Pembangunan dan Pendidikan Vokasi Pertanian

Politeknik Pembangunan Pertanian Manokwari, 31 Juli 2021

e ISSN : 2774-1982

DOI : https://doi.org/10.47687/snppvp.v2i1.178

Mazumder, A.C., Khatum, S., Nooruzzaman, M., Chowdhury, E.H., Das, P.M., \& Islam M.R. (2012). Isolation and identification of Newcastle disease viruses from field outbreaks in chicken and pigeon. Bangladesh Veterinarian, 29 (2): 41-48.

Mohammad, M.H., Kandeil, A., Akhazindar, M., Salam, E.T.A., \& Ali, M.A. (2020). Isolation of Newcastle disease virus from wild migration birds in Eygypt. J. Word. Poult. Res., 10 (3): 520-526.

Msoffe, P.L.M., Chiwanga, G.H., Cardona, C.J., Miller, P.J., \& Suarez, D.L. (2019). Isolation and characterization of Newcastle disease virus from live bird markets in Tanzania. Avian Dis., 63(4): 634-640.

Nasrullah, Nudirman, M., Ramadany, A., Ermansyah, L., Munawar, J.A., Nurzamin, A., Nurrohman, R.A., Priyono, Zaironi, A., \& Kurniawan, V.A. (2019). Statistika Peternakan dan Kesehatan Hewan, Livestock and Health Statistics. Direktorat Jenderal Peternakan dan Kesehatan Hewan, Kementerian Pertanian. Jakarta.

OIE. (2021). Manual of Diagnostic Test and Vaccine 2021. OIE Word Organization for Animal Health. Paris. OIE. 2021. Terrestrial Manual 2021, Chapter 3.3.14. Newcastle Disease (Infection with Newcastle Disease Virus. OIE, World Organization for Animal Health, Paris.

Okpanachi, J.U., Umoh, J.U., Kia, G.S.N., \& Dzikwi, A.A. (2020). Dtection of Newcastle disease virus (NDV) in Laughing Doves and the risk of spread to backyard poultry. Folia Veterinaria, 64 (3): 1-12.

Shanmuganathan, L., Anggoro, D., \& Wibowo, M.H. (2017). Newcastle disease viru detection from chicken organ samples using reverse transciptase polymerase chain reaction. J. Sain Veteriner, 35 (1): 127-135.

Thomazelli, L.M., Araujo, J., Ferreira, C.S., Hurtado, R., Oliveira, D.B., Ometto, T., Golono, M., Sanfilippo, Demestrio, C., Figuiredo, M.L., \& Durigon, E.L. (2020). Molecular surveillance of Newcastle disease virus in domestic and wild birds on the North Eastern Coast and Amazon biome of Brazil. Braz J. Poult Sci., 14 (1). 